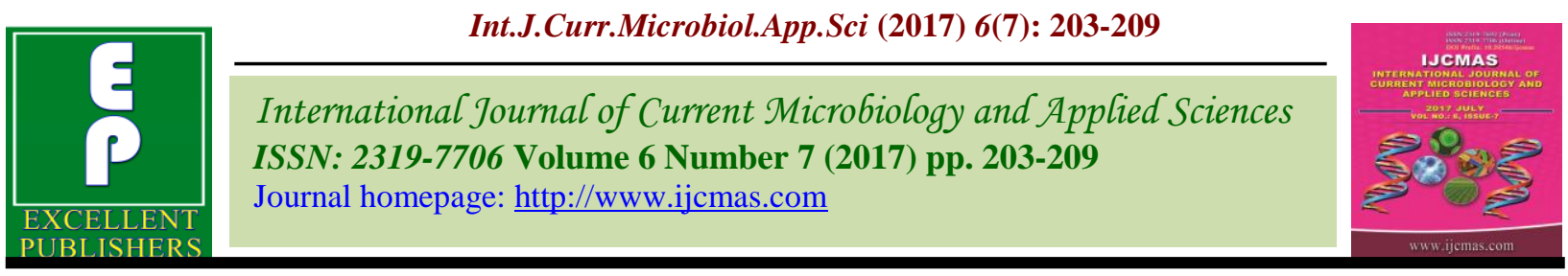

Original Research Article https://doi.org/10.20546/ijcmas.2017.607.024

\title{
Population Dynamics of Thrips, Thrips tabaci Lindemann in American Cotton (Gossypium hirsutum)
}

\author{
Arun Janu*, K.K. Dahiya and Pritish Jakhar \\ Department of Entomology, Chaudhary Charan Singh Haryana Agricultural University, \\ Hisar - 125004, Haryana, India \\ *Corresponding author
}

\section{A B S T R A C T}

The population dynamics of thrips, Thrips tabaci Lindemann along with their correlation with abiotic factors were studied during 2014 and 2015 at the Cotton Research Area, CCS

Keywords Haryana Agricultural University, Hisar. During the $1^{\text {st }}$ season, the incidence of thrips was

Thrips,

Thrips tabaci,

American cotton,

Abiotic factors.

Article Info

Accepted:

04 June 2017

Available Online:

10 July 2017 recorded from the $27^{\text {th }}$ SMW (standard meteorological week) onwards and reached to its peak at $33^{\text {rd }}$ SMW with the range of 12.89 to 58.27 thrips/leaf. The maximum and minimum mean thrips population was recorded in RCH 314 BGII (16.13thrips/leaf) and $\mathrm{H}$ 1226 (3.52thrips/leaf) genotype, respectively. During the $2^{\text {nd }}$ season the incidence of thrips was commenced at $25^{\text {th }} \mathrm{SMW}$. The peak of the thrips population reached in $31^{\text {st }} \mathrm{SMW}$ and it ranged from 14.68 to 36.85 thrips/leaf. The minimum mean thrips population of 4.64 nymphs/leaf was recorded in the H 1226 genotype whereas RCH 314 BGII had the maximum mean thrips population of 13.02 nymphs/leaf. Correlation studies revealed that during $1^{\text {st }}$ season all the weather parameters were non-significantly correlated with the thrips population whereas, during $2^{\text {nd }}$ season maximum temperature correlated significantly negative with thrips population while minimum temperature, morning and evening relative humidity correlated significantly positive.

\section{Introduction}

Cotton is important commercial crop grown under diverse agro-climatic conditions around the world and vulnerable to attacked from several insect pests. In India with the introduction and successful implementation of transgenic $B t$ cotton not only solved the problem of bollworm complex but also cut down the number of insecticidal spray which probably leads sever incidence of sucking pest and occupied major pest status and cause considerable damage in traditional and $B t$ cotton in India at present (Zala et al., 2014). Sap feeders have been reported to cause loss in yield to the extent of $8.45 \mathrm{q} /$ ha in hirsutum cotton (Radhika et al., 2006). Among the various sap feeding insect pests, thrips, Thrips tabaci Lindemann is major factor limiting profitable cultivation of cotton. A common sign of a heavy thrips infestation is the distorted leaves that have turned brownish around the edges and cup upward. Thrips also found on underside of the leaves damaging them by piercing the epidermis of the tissues and sucking the sap oozing out of wounds (Sanjta and Chauhan, 2015). As a result, leaves became slivery due to formation of white patches or streaks which finally caused scarring and distortion of leaves (Patel and 
Patel, 2014). Different weather factors found to have positive association with thrips population (Soni and Dhakad, 2016) for their development and seasonal incidence. The knowledge about incidence of pest during cropping season and its possible dynamics helps in designing pest management strategies hence present study on population dynamics of cotton thrips was undertaken during Kharif seasons of 2014 and 2015 to fulfil objectives.

\section{Materials and Methods}

The field experiment were conducted during Kharif 2014 and 2015 at Cotton Research field area, CCS Haryana Agricultural University, Hisar in unprotected with three replicated. The plot having 5 rows of $5 \mathrm{~m}$ each for each treatment. The seeds of 23 genotypes were sown at 2 seeds/hill on $18^{\text {th }}$ May, 2014 and $16^{\text {th }}$ May, 2015 by hand dibbling method. Gap filling was done within 5-7 days after emergence of the crop and thinning was done at 15 days after emergence of the crop, keeping one healthy seedling/hill.

The observations on population of thrips (nymph and adult) were recorded at weekly interval from $23^{\text {rd }}$ to $41^{\text {st }}$ SMW on three leaves (each from top, middle and bottom) at five randomly selected plants from each replication (Zala et al., 2014). The data pertaining to seasonal incidence of thrips of cotton crop were compared with various environmental factors. The relation between weather parameters and thrips of cotton was studied and simple correlation was worked out.

\section{Results and Discussion}

Population dynamics of Thrips tabaci on cotton during Kharif 2014

The population of thrips commenced at $27^{\text {th }}$ SMW (Fig. 1). At $27^{\text {th }}$ SMW, maximum thrips population was recorded on $\mathrm{RCH} 314$ BGII (14.33 thrips/leaf) and it were statistically on par with $\mathrm{KCH} 14 \mathrm{~K} 59$ BGII (8.89 thrips/leaf), Western Niroga 151 BGII (11.44 thrips/leaf), GBCH 85 BGII (11.44 thrips/leaf) and S $07 \mathrm{H} 878$ BGII (12.67 thrips/leaf). Minimum thrips population were recorded on RCH 653 BGII and VICH 310 BT II (1.67 thrips/leaf) and it were statistically on par with HHH 223 (2.22 thrips/leaf), H 1226 (2.22 thrips/leaf), PRCH 333 BGII (2.22 thrips/leaf), KSCH 210 BGII (2.56 thrips/leaf), Bioseed 6588 BGII (3.22 thrips/leaf), PCH $876 \mathrm{BT}$ (3.33 thrips/leaf), SP 7007 BGII (3.44 thrips/leaf), SP 7010 (3.44 thrips/leaf), PCH 877 BGII (3.67 thrips/leaf) and SP 7171 BGII (4.67 thrips/leaf). Standard meteorological week $27^{\text {th }}$ onwards, increasing trend in thrips population were observed and reached to its peak at $33^{\text {rd }}$ SMW (Fig. 1) with the range of 12.89 to 58.27 thrips/leaf. Genotype RCH 314 BGII were recorded with maximum population of 58.27 thrips/leaf and it were statistically on par with Western Niroga 151 BGII (49.84 thrips/leaf) and S 07 H 878 BGII (51.49 thrips/leaf) while minimum were 12.89 thrips/leaf on genotype $\mathrm{H} 1226$ and it were statistically on par with HHH 223 (14.00 thrips/leaf), $\mathrm{RCH} \quad 653$ BGII (16.16 thrips/leaf), PCH 876 BT (17.43 thrips/leaf), SP 7010 (18.00 thrips/leaf) and PRCH 333 BGII (18.57 thrips/leaf). After $33^{\text {rd }}$ SMW, population started declining till $41^{\text {st }} \mathrm{SMW}$. At $41^{\text {st }}$ SMW, maximum population of 1.44 thrips/leaf were observed on RCH 314 BGII and it were statistically on par with Western Niroga 151 BGII (1.23 thrips/leaf) and S $07 \mathrm{H}$ 878 BGII (1.27 thrips/leaf). Minimum population of thrips were observed on $\mathrm{H} 1226$ (0.32 thrips/leaf) and it were statistically on par with $\mathrm{HHH} 223$ (0.34 thrips/leaf), RCH 653 BGII (0.40 thrips/leaf), PCH 876 BT (0.43 thrips/leaf), SP 7010 (0.44 thrips/leaf), PRCH 333 BGII (0.46 thrips/leaf) and PCH 877 BGII (0.47 thrips/leaf). Mean population 
of thrips were recorded on different genotypes of cotton and it ranged from 3.52 to 16.13 thrips/leaf (Table 1). Maximum population was recorded on RCH 314 BGII (16.13 thrips/leaf) while, minimum was on $\mathrm{H} 1226$ (3.52 thrips/leaf) and it was statistically on par with HHH 223 (3.77thrips/leaf).

\section{Population dynamics of $T$. tabaci on cotton during Kharif 2015}

The thrips population commenced at $25^{\text {th }}$ SMW is presented in figure 2 . The significant difference among the thrips population was observed at $26^{\text {th }} \mathrm{SMW}$ and it ranged from 0.11 to 2.22 thrips/leaf. Maximum population was 2.22 thrips/leaf on S $07 \mathrm{H} 878 \mathrm{BGII}$ and it were statistically on par with $\mathrm{RCH} 314$ BGII (1.22 thrips/leaf) and Western Niroga 151 BGII (1.33 thrips/leaf). Minimum population were 0.11 thrips/leaf on $\mathrm{HHH} 223$, RCH 653 BGII, SP 7010, PRCH 333 BGII and $\mathrm{PCH} 406 \mathrm{BT}$ and these were statistically on par with rest of the genotypes. Peak population reached in $31^{\text {st }}$ SMW (Fig. 2) and it ranged from 14.68 to 36.85 thrips/leaf. Genotype RCH 314 BGII (36.85 thrips/leaf) was recorded with maximum population and it was statistically on par with S $07 \mathrm{H} 878$ BGII (33.78 thrips/leaf) while, minimum was on HHH 223 (14.68 thrips/leaf) and it were statistically on par with H 1226 (14.86 thrips/leaf), $\quad$ RCH 653 BGII (15.59 thrips/leaf), PRCH 333 BGII (16.44 thrips/leaf), SP 7010 (16.51 thrips/leaf) and PCH 876 BT (16.98 thrips/leaf). After $31^{\text {st }}$, the thrips population went to decline till $41^{\text {st }}$ SMW.

At $41^{\text {st }}$, non-significant population were recorded among the different genotypes. Mean population of thrips were recorded on different genotypes of cotton and it ranged from 4.64 to 13.02 thrips/leaf (Table 1). Minimum population was recorded on $\mathrm{H} 1226$ (4.64 thrips/leaf) and it was statistically on par with HHH 223 (4.71 thrips/leaf) while,
Maximum were on RCH 314 BGII (13.02 thrips/leaf).

\section{Population dynamics of $T$. tabaci on cotton during both seasons (2014 and 2015)}

During pooled analysis of both the years (2014 and 2015), the population of thrips commenced at $25^{\text {th }}$ SMW is presented in figure 3. The significant difference was observed among the population of thrips on different genotypes of cotton at $26^{\text {th }}$ SMW. Maximum population were recorded on genotype S $07 \mathrm{H} 878$ BGII (1.11 thrips/leaf) followed by SP 7007 BGII (0.56 thrips/leaf) and $\mathrm{RCH} 314$ BGII (0.61 thrips/leaf). Minimum population were recorded on $\mathrm{HHH}$ 223, RCH 653 BGII, SP 7010, PRCH 333 BGII and PCH 406 BT (0.06 thrips/leaf) and it were statistically on par with $\mathrm{H} 1226$ (0.07 thrips/leaf), PCH 876 BT (0.11 thrips/leaf), SP 7171 BGII (0.11 thrips/leaf), KDCHH 541 BGII (0.11 thrips/leaf), BIOSEED 6588 BGII (0.11 thrips/leaf), KSCH 210 BGII (0.11 thrips/leaf) and KSCH 209 BGII (0.16 thrips/leaf). Standard meteorological week $26^{\text {th }}$ onwards population of thrips started increasing and reached to its peak at $33^{\text {rd }}$ SMW (Fig. 3). At peak, population ranged from 11.12 to 41.57 thrips/leaf. Maximum population was recorded on $\mathrm{RCH} 314$ BGII (41.57 thrips/leaf) and it were statistically on par with $\mathrm{KCH} \quad 14 \quad \mathrm{~K} \quad 59$ BGII (33.49 thrips/leaf), GBCH 85 BGII $\quad$ (34.02 thrips/leaf), Western Niroga 151 BGII (35.42 thrips/leaf) and S $07 \mathrm{H} 878$ BGII (37.14 thrips/leaf). Genotype H $1226 \quad$ (11.12 thrips/leaf) was recorded with minimum population of thrips and it were statistically on par with HHH 223 (11.99 thrips/leaf), RCH 653 BGII (13.33 thrips/leaf), PCH 876 BT (14.40 thrips/leaf), SP $7010 \quad$ (14.65 thrips/leaf), $\quad$ PRCH 333 BGII $\quad$ (14.87 thrips/leaf), $\quad$ PCH 877 BGII $\quad$ (15.73 thrips/leaf), Bioseed6588 BGII (16.35 thrips/leaf), $\quad$ VICH $310 \quad$ BTII $\quad$ (16.64 thrips/leaf), $\quad \mathrm{KSCH} \quad 210 \quad$ BGII $\quad(17.12$ 
thrips/leaf) and SP 7007 BGII (18.39 thrips/leaf). After $33^{\text {rd }}$ SMW, thrips population started declining and last observation was recorded on $41^{\text {st }}$ SMW before picking. Maximum thrips population was recorded on $\mathrm{RCH} 314$ BGII (1.16 thrips/leaf) and it were statistically on par with $\mathrm{KCH} 14 \mathrm{~K} 59$ BGII (0.90 thrips/leaf), GBCH 85 BGII (0.95 thrips/leaf), Western
Niroga 151 BGII (0.99 thrips/leaf) and S $07 \mathrm{H}$ 878 BGII (1.00 thrips/leaf). Mean population of thrips were recorded on different genotypes of cotton and it ranged from 4.08 to 14.58 thrips/leaf (Table 1). Maximum thrips population were recorded on RCH 314 BGII (14.58 thrips/leaf) while, minimum were on $\mathrm{H}$ 1226 (4.08 thrips/leaf).

Table.1 Average population of thrips (Thrips tabaci) on American cotton genotypes

\begin{tabular}{|l|l|c|c|c|}
\hline \multirow{2}{*}{ S. No. } & \multirow{2}{*}{ Genotypes } & \multicolumn{3}{|c|}{ Thrips/leaf } \\
\cline { 3 - 5 } $\mathbf{1}$ & SP 7010 & $\mathbf{2 0 1 4}$ & $\mathbf{2 0 1 5}$ & Pooled \\
\hline $\mathbf{2}$ & PRCH 333 BGII & $4.93(2.44)$ & $5.34(2.52)$ & $5.14(2.48)$ \\
\hline $\mathbf{3}$ & VICH 310 BT II & $4.94(2.44)$ & $5.59(2.57)$ & $5.26(2.50)$ \\
\hline $\mathbf{4}$ & GBCH 85 BG II & $5.16(2.48)$ & $5.74(2.60)$ & $5.45(2.54)$ \\
\hline $\mathbf{5}$ & KSCH 210 BG II & $12.88(3.73)$ & $10.38(3.37)$ & $11.63(3.55)$ \\
\hline $\mathbf{6}$ & S 07 H 878 BG II & $5.68(2.58)$ & $6.04(2.65)$ & $5.86(2.62)$ \\
\hline $\mathbf{7}$ & SP 7007 BGII & $14.26(3.91)$ & $11.78(3.57)$ & $13.02(3.74)$ \\
\hline $\mathbf{8}$ & KSCH 209 BG II & $5.99(2.64)$ & $7.16(2.86)$ & $6.57(2.75)$ \\
\hline $\mathbf{9}$ & KSCH 541 BGII & $11.14(3.48)$ & $8.92(3.15)$ & $10.03(3.32)$ \\
\hline $\mathbf{1 0}$ & KDCHH 541 BGII & $7.48(2.91)$ & $7.49(2.91)$ & $7.48(2.91)$ \\
\hline $\mathbf{1 1}$ & PCH 876 BT & $8.75(3.12)$ & $8.26(3.04)$ & $8.50(3.08)$ \\
\hline $\mathbf{1 2}$ & PCH 406 BT & $4.78(2.40)$ & $5.19(2.49)$ & $4.98(2.45)$ \\
\hline $\mathbf{1 3}$ & KCH 14 K 59 BG II & $8.15(3.02)$ & $8.18(3.03)$ & $8.16(3.03)$ \\
\hline $\mathbf{1 4}$ & NCS 9002 BG II & $12.73(3.71)$ & $10.06(3.33)$ & $11.40(3.52)$ \\
\hline $\mathbf{1 5}$ & PCH 877 BG II & $7.64(2.94)$ & $7.81(2.97)$ & $7.72(2.95)$ \\
\hline $\mathbf{1 6}$ & WESTERN NIROGA 151 BG II & $5.25(2.50)$ & $5.80(2.61)$ & $5.52(2.55)$ \\
\hline $\mathbf{1 7}$ & ANK 3028 BG II & $13.76(3.84)$ & $10.82(3.44)$ & $12.29(3.65)$ \\
\hline $\mathbf{1 8}$ & SP 7171 BG II & $7.48(2.91)$ & $7.79(2.96)$ & $7.63(2.94)$ \\
\hline $\mathbf{1 9}$ & RCH 653 BG II & $6.68(2.77)$ & $7.27(2.88)$ & $6.97(2.82)$ \\
\hline $\mathbf{2 0}$ & BIOSEED 6588 BG II & $4.20(2.28)$ & $4.95(2.44)$ & $4.58(2.36)$ \\
\hline $\mathbf{2 1}$ & RCH 314 BG II & $5.60(2.57)$ & $5.84(2.62)$ & $5.72(2.59)$ \\
\hline $\mathbf{2 2}$ & HHH 223 & $16.13(4.14)$ & $13.02(3.74)$ & $14.58(3.95)$ \\
\hline $\mathbf{2 3}$ & H 1226 & $3.77(2.18)$ & $4.71(2.39)$ & $4.24(2.29)$ \\
\hline & C.D. & $3.52(2.13)$ & $4.64(2.37)$ & $4.08(2.25)$ \\
\hline & SE(m) & $(0.25)$ & $(0.18)$ & $(0.20)$ \\
\hline
\end{tabular}

Figures in parentheses are $\sqrt{X+1}$ transformed values

Table.2 Correlation of thrips population with weather parameter

\begin{tabular}{|c|c|c|c|}
\hline \multirow{2}{*}{ Pest } & \multicolumn{3}{|c|}{ Thrips } \\
\cline { 2 - 4 } & $\mathbf{2 0 1 4}$ & $\mathbf{2 0 1 5}$ & Pooled \\
\hline Temperature (maximum) & -0.244 & $-0.593^{* *}$ & $-0.493^{*}$ \\
\hline Temperature (minimum) & 0.409 & $0.543^{*}$ & $0.529^{*}$ \\
\hline RH (morning) & 0.268 & $0.673^{* *}$ & $0.585^{*}$ \\
\hline RH (evening) & 0.412 & $0.677^{* *}$ & $0.745^{*}$ \\
\hline Rainfall & -0.176 & -0.079 & -0.129 \\
\hline Wind Speed & 0.121 & 0.367 & 0.247 \\
\hline Sunshine hours & 0.235 & -0.442 & -0.565 \\
\hline
\end{tabular}

$*$ Significant at $5 \%, * *$ Significant at $1 \%$ 
Fig.1 Population dynamic of thrips in relation to weather parameters 2014

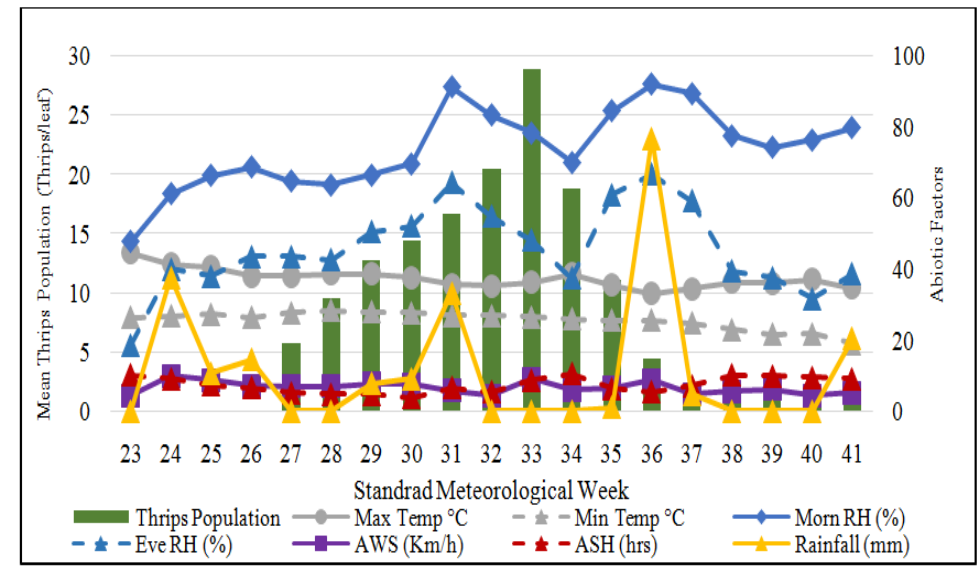

Fig.2 Population dynamic of thrips in relation to weather parameters 2015

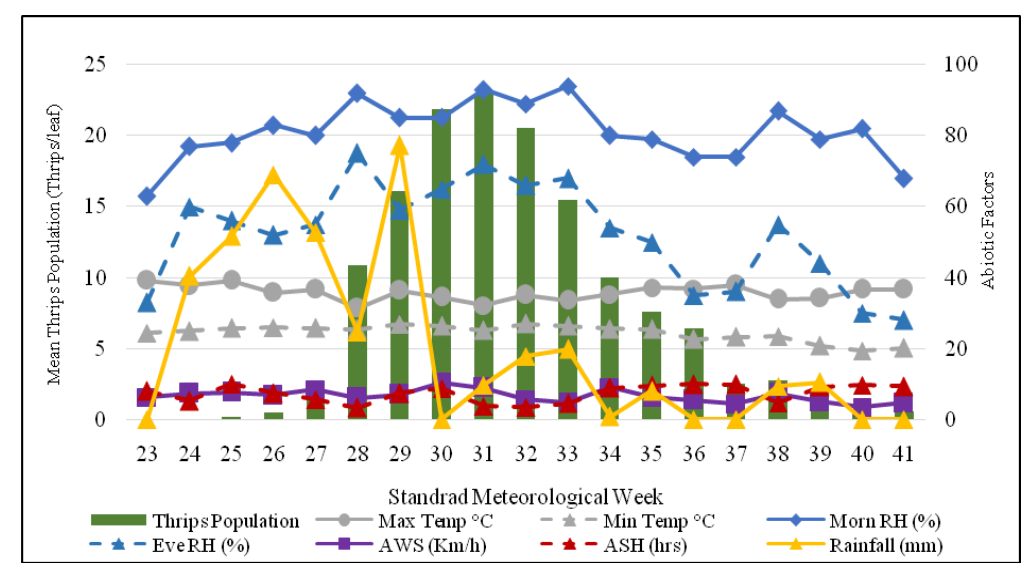

Fig.3 Population dynamic of thrips in relation to pooled weather parameters

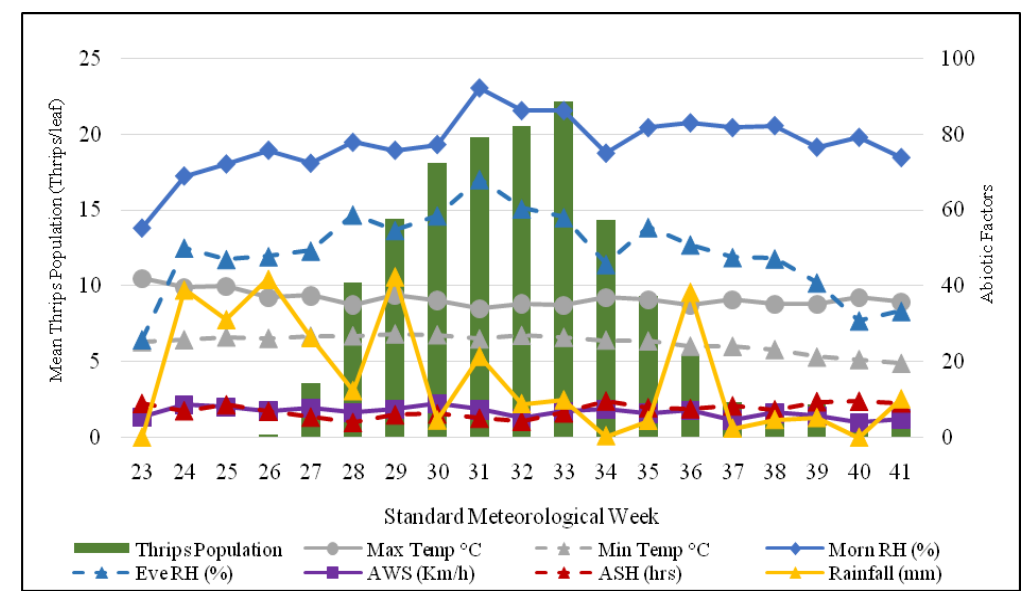

The present findings are in agreement with Kengegowda et al., (2005) who reported incidence of thrips started in the month of
August. Roomi (2015) reported that the peak incidence was observed at $33^{\text {rd }} \mathrm{SMW}$ at Hisar. Bhute et al., (2012) conducted the experiment 
at Parbhani (MH) during 2007-08 and observed that thrips remained active from $32^{\text {nd }}$ to $52^{\text {nd }}$ SMW and reached to its peak at $40^{\text {th }}$ SMW with 110.10 thrips/3 leaves. Similar results were attained by Arshad and Suhail (2010) who reported that the thrips attained its peak during third week of August. Prasad and Rao (2008) reported that incidence started in month of June and remained active upto $52^{\text {nd }}$ SMW. The findings of Babu and Meghwal (2014) are not in conformity with our present study and they reported that the maximum thrips population was observed during the 39-41 SMW.

\section{Correlation with the weather parameters and $T$. thrips during 2014}

Non-significant correlations were recorded between thrips population and weather parameters are presented in table 2 .

\section{Correlation with the weather parameters and $T$. thrips during 2015}

The data showed in the table 2 presented the correlation coefficient between the thrips populations with weather parameters. Maximum temperature correlated significantly negative with population and it were $\mathrm{r}=-593^{* *}$. The correlation coefficient of population with minimum temperature, morning and evening relative humidity were $\mathrm{r}=0.543^{*}, 0.673^{* *}$ and $0.677^{*} *$, respectively.

\section{Correlation with the weather parameters and $T$. thrips during both seasons}

During pooled analysis of both the years (2014 and 2015), similar trend were followed as in kharif 2015, significant and negative correlation of population with maximum temperature were $\mathrm{r}=-0.493 *$ while, significant and positive $\mathrm{r}=0.529^{*}, 0.585^{*}$ and $0.745^{* *}$ with minimum temperature, morning and evening temperature, respectively presented in the table 2 .
These present findings are in agreement with Saleem et al., (2013) who found that the weather factors were non-significantly correlated with thrips populations during 2008 while only relative humidity showed positive correlation in 2009. Zala et al., (2014) conducted an experiment at Anand during kharif, 2011-12 and showed that the maximum temperature was significantly negative association with the thrips population. Selvaraj and Adiroubane (2012) they reported that thrips population was positive correlated with temperature, relative humidity and sunshine hour. Gosalwad et al., (2009) who reported negative significant correlation with maximum temperature, the results are in conformity with the present findings.

It may be concluded that the climatic factors determined seasonal activity and population dynamics of thrips in cotton. This information generated in present study would be helpful in developing efficient pest management strategies against insect pests of cotton crop for increased production efficiency, profit, besides safety to the environment.

\section{References}

Arshad, M. and Suhail, A. 2010. Studying the sucking insect pests community in transgenic Bt cotton, Int. J. Agric. Biol. 12: 764-776.

Babu, S.R. and Meghwal, M.L. 2014. Population dynamics and monitoring of sucking pests and bollworms on $B t$ cotton in humid zone of southern Rajasthan, Bioscan. 9(2): 629-632.

Bhute, N.K., Bhosle, B.B., Bhede, B.V. and More, D.G. 2012. Population dynamics of major sucking pests of $B t$ cotton, Indian J. Entomol. 74(3): 246-252.

Gosalwad, S.S., Kamble, S.K., Wandnerkar, D.W. and Awaz, B.H. 2009. Population dynamics of major insect pests of cotton and their natural enemies, J. Cotton Res. 
Dev. 23:117-125.

Kengegowda, N., Patil, B.V. and Bheemanna, M. 2005. Population dynamics of insect pests on $B t$, Non- $B t$ and popular hybrid cotton in tungabhadra project area of Karnataka State. Karnataka J. Agr. Sci. 18: 383-388.

Patel, Y and Patel, P. 2014. Evaluation of cotton (Gossypium hirsutum L.) genotypes for their reaction to Thrips tabaci Lindemann. Res. Environ. Life Sci. 7(4): 267-270.

Prasad, N.V.V.S.D. and Rao, N.H. 2008. Field evaluation of $B t$ cotton hybrids against insect pest complex under rainfed conditions. Indian J. Entomol. 70: 330-336.

Radhika, P., Sudhakar, K., Sahadeva Reddy, B. and Basha Mohiddin, S. 2006. Field evaluation of cotton genotype against Amrasca biguttulla biguttula (Dist.). J. Cotton Res. Dev. 20:134-134.

Roomi. 2015. Population dynamics of different insect pests and arthropods natural enemies on various $B t$ cotton gene events, M.Sc. Thesis, Chaudhary Charan Singh Haryana Agricultural University, Hisar, Haryana.
Saleem, M.W., Ahmed, S., Wakil, W. and Sahi, S.T. 2013. Resistance to thrips (Thrips tabaci) in $\mathrm{Bt}$ cotton genotypes in Punjab, Pakistan, based on population dynamics and plant morphochemical properties. Int. J. Agr. Biol. 15: 331-336.

Sanjta, S. and Chuahan, U. 2015. Survey of thrips (Thysanoptera) and their natural enemies in vegetables from mid hills of Himachal Pradesh. Ecoscan. 9(3\&4): 713-715.

Selvaraj, S. and Adiroubane, D. 2012. Influence of weather parameters on the incidence of thrips, Thrips tabaci Lindemann in cotton. J. Cotton Res. Dev. 26(2): 234-237.

Soni, R. and Dhakad, N.K. 2016. Seasonal dynamics of Thrips tabaci (Lindemann) and their correlation with weather parameters on transgenic $B t$ cotton. Int. J. Adv. Res. 4(8): 1486-1488.

Zala, M.B., Patel, C.K. and Bharpoda, T.M. 2014. Impact of sowing periods on incidence of sucking pests and their relation to weather parameters in $B t$ cotton. Ecocan. 6: 345-354.

\section{How to cite this article:}

Arun Janu, K. K. Dahiya and Pritish Jakhar. 2017. Population Dynamics of Thrips, Thrips Tabaci Lindemannin American Cotton (Gossypium Hirsutum). Int.J.Curr.Microbiol.App.Sci. 6(7): 203-209. doi: https://doi.org/10.20546/ijcmas.2017.607.024 